副咽頭間隙に発生した悪性リンパ腫の 1 症例

山谷 浩信 ·小林 一豊

\title{
Malignant Lymphoma in the Parapharyngeal Space ; A Case Report
}

\author{
Hironobu Yamaya and Kazutoyo Kobayashi \\ (Hakodate Municipal Hospital)
}

Malignant lymphoma in the parapharyngeal space is very rare in Japan.

A 68-year-old male with a malignant lymphoma in the parapharyngeal space is reported. In this case, preoperative diagnosis from fine needle aspiration and open biopsy was difficult.

The malignant lymphoma was discovered on postoperative histopathological examination.

Key words : malignant lymphoma, parapharyngeal space, biopsy

\section{はじめに}

副咽頭間隙は解剖学的に非常に複雑な部位であるが, 近年では CT P MRI などの画像診断技術の発達により， その報告は増えてきている．副咽頭間隙腫瘍の大多数は 良性腫瘍であり, 悪性腫瘍が発生することは稀である。

一方, 耳鼻咽喉・頭頸部領域は悪性リンパ腫の好発部位 であるが，副咽頭間隙に発生したとする報告は少ない。 今回我々は, 副咽頭間隙に発生した腫瘤で術前に診断が 困難であり，術後の病理組織学的所見で悪性リンパ腫と 確定診断された症例を経験したので, 若干の考察を加え て報告する。

患者 : 68歳, 男性.

主訴：左下顎角部腫瘤.

既往歴 : 高血圧.

家族歴：特記すべきことなし．

現病歴: 平成 6 年 3 月頃, 左下顎角部の圧痛のある腫 瘤に気付き，3月29日に当科を受診した。

初診時所見：左下顎角部から靧下部にかけて, 約 25 $\times 30 \mathrm{~mm}$ 大の弾性硬の腫瘤を認めた．圧痛を認めたが，
周囲との癒着は認められず，拍動は触知しなかった。 ロ 腔内は異常所見を認めず，その他の耳鼻咽喉科領域に異 常を認めなかった．脳神経症状は認められなかった。

血液所見：白血球軽度上昇, $\mathrm{CRP}$ 上昇を認めた以外

は, 腫瘍マーカーを含めて, 異常を認めなかった。

画像診断：CT では左副咽頭間隙下後方に約 $25 \times 30$ $\mathrm{mm}$ の辺縁不整で境界が一部不明膫な内部が不均一飞造 影される腫瘍像を認めた(図 1). MRI では T1 強調画 像で筋肉と等信号, T2 強調画像では高信号の, 辺縁や や不整で境界が明膫, 内部がほぼ均質な, Gd でよく造 影される腫瘍像を認めた．耳下腺との間は脂肪組織によ り境され，内頸動・静脈は前方に圧排されていた(図 2 ). ${ }^{67} \mathrm{Ga}$ シンチでは異常な取り込みは認められなかった。 穿刺吸引細胞診 : Class III.

以上の検査からは, 悪性腫瘍, 壊死性リンパ節炎, 神 経原性腫瘍などが疑われるため, 頸部外切開による生検 を平成 6 年 5 月 17 日に行ったが，確診が得られなかった ため, 7 月17日, 術中迅速診断を含め, 摘出術を行った. 手術所見：全身麻酔下に耳下部より顎下部にかけて約 $10 \mathrm{~cm}$ の皮膚切開を行い, 胸鎖乳突筋を後方へ挙上する と, 下顎角裏側に被膜で包まれた腫瘤が露出した．被膜 


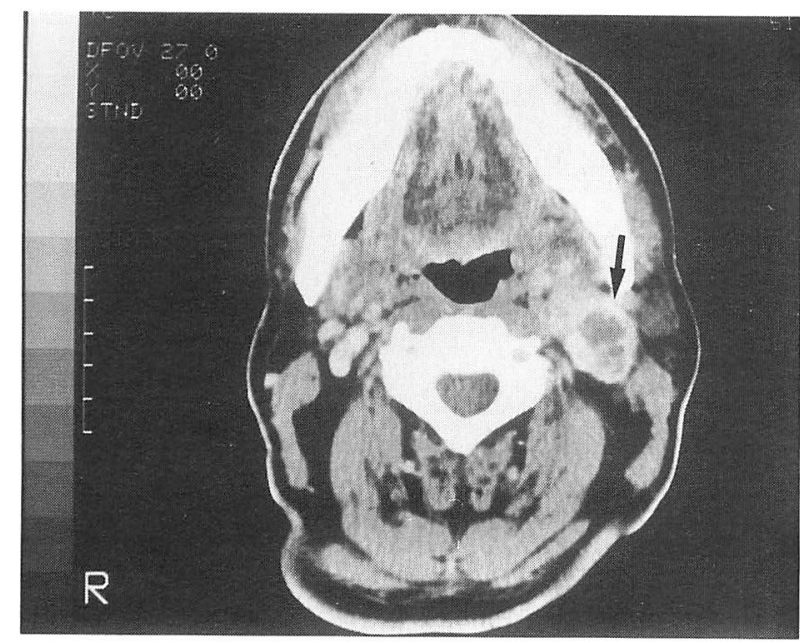

図 1 CT (enhanced)

左副咽頭間隙下後方に辺縁不整で境界が一部不明瞭な内 部が不均一に造影される腫瘍 (矢印).

に小切開を加え内部の組織を 2 回, 術中迅速診断に提出 したが悪性所見を認めなかったため，被膜を閉鎖し創洗 浄を行った後, 剝離を進めた。腫瘤は用手にて容易に剝 離できた．耳下腺との間は脂肪組織が存在し連続性はな く, 頸動脈・内頸動脈は前方に圧排されていたが，癒着 は認めなかった．出血量は $170 \mathrm{ml} て ゙$ でった。

腫瘍は $40 \times 35 \times 30 \mathrm{~mm}$ 大であり, 表面は被膜に覆わ れ一部結節状で弾性硬であった。割面は黄色〜白色で一 部壊死を伴い, 充実性であった(図 3 ).

病理所見 : 壊死を伴い, び慢性に増生する腫瘍細胞が 認められた(図 4 ). 免疫組織で LCA(+), MB1(+), L26 $(+)$ でKeratin(-), $\operatorname{EMA}(-), \operatorname{MT} 1(-), \operatorname{UCHL1}(-)$ であった(図 5 )。最終的に悪性リンパ腫 (diffuse large cell, B cell) と診断された.

術後経過: Stage 1 の悪性リンパ腫として, 内科にて, CHOP 療法 (cyclophosphamide ; $1200 \mathrm{mg}$, day 1, pirarubicin ; $80 \mathrm{mg}$, day 1 , vincristine ; $2 \mathrm{mg}$, day 1 , predonisolone； $80 \mathrm{mg}$, day 1 5) 9 クール施行し, その後 の検植でリンパ節腫脹認めず，外来経過観察中である.

\section{考察}

副咽頭間隙は頭蓋底から舌骨の高さにあり, 内側は咽 頭收縮笳, 外側は下顎骨之耳下腺, 前方は内・外側翼突 筋, 後方は頸椎により形成される間隙である。この間隙 は茎状突起により, 茎突前区と茎突後区に分けられる.

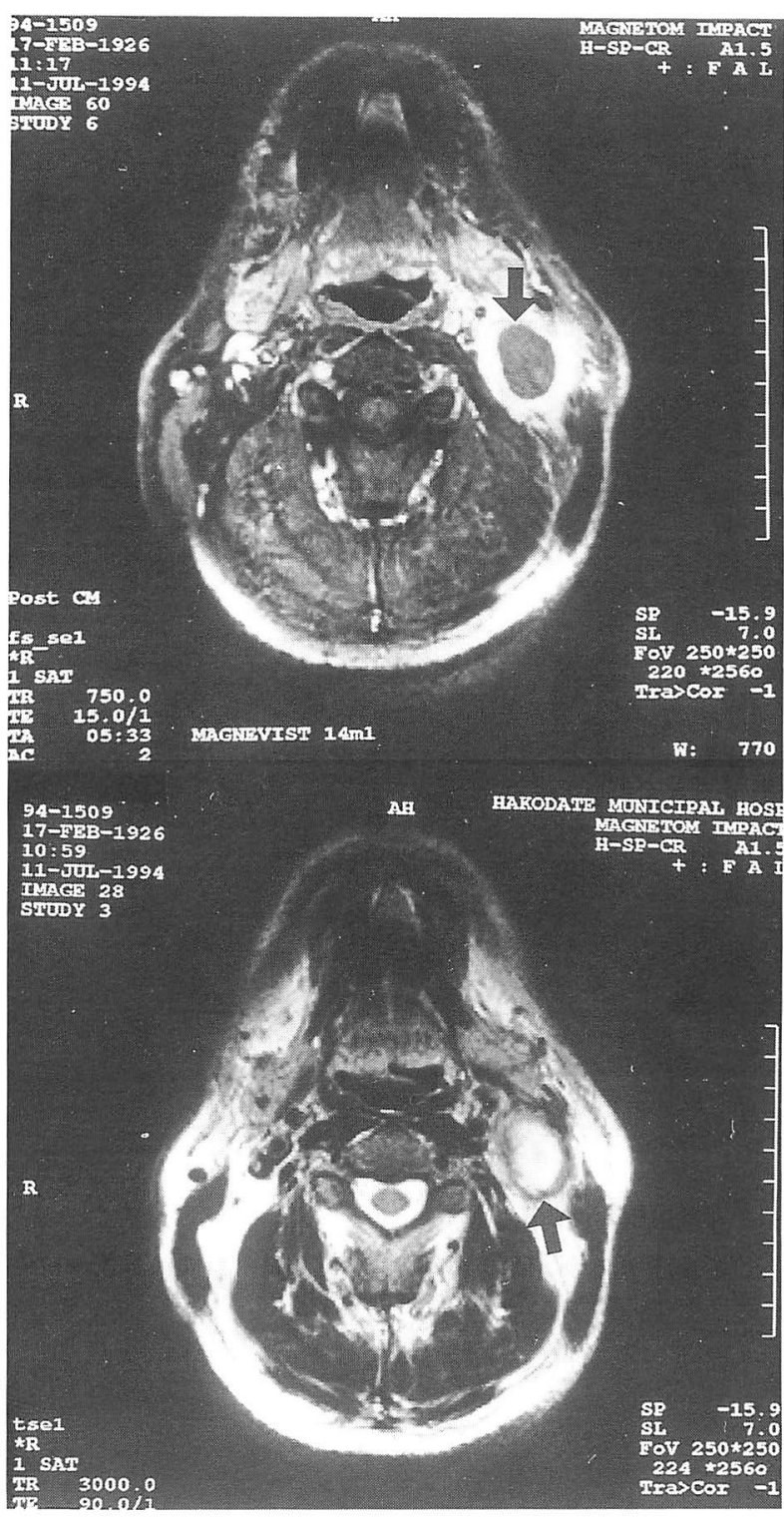

図 2 MRI

(上段: T1 強調画像, 下段 : T2 強調画像) 辺縁やや不整で境界明瞭, 内部はほぼ均質, Gd で造影 される腫痬 (矢印).

前者には, 主に脂肪組織から成る狭義の副咽頭間隙が存 在し, 後者には, 頸動脈, 内頸静脈, 交感神経幹, 第 9 〜 12脳神経, リンパ節を含む頸動脈間隙が存在する.こ の上うに, 様々な臓器を含み, その隣接部には小唾液腺 や大唾液腺が位置しているために, 副咽頭間隙に発生す る腫瘍は組織学的に多彩である。一方, 耳鼻咽㗋・頭頸 部領域は悪性リンパ腫の好発部位であり，そのほとんど 


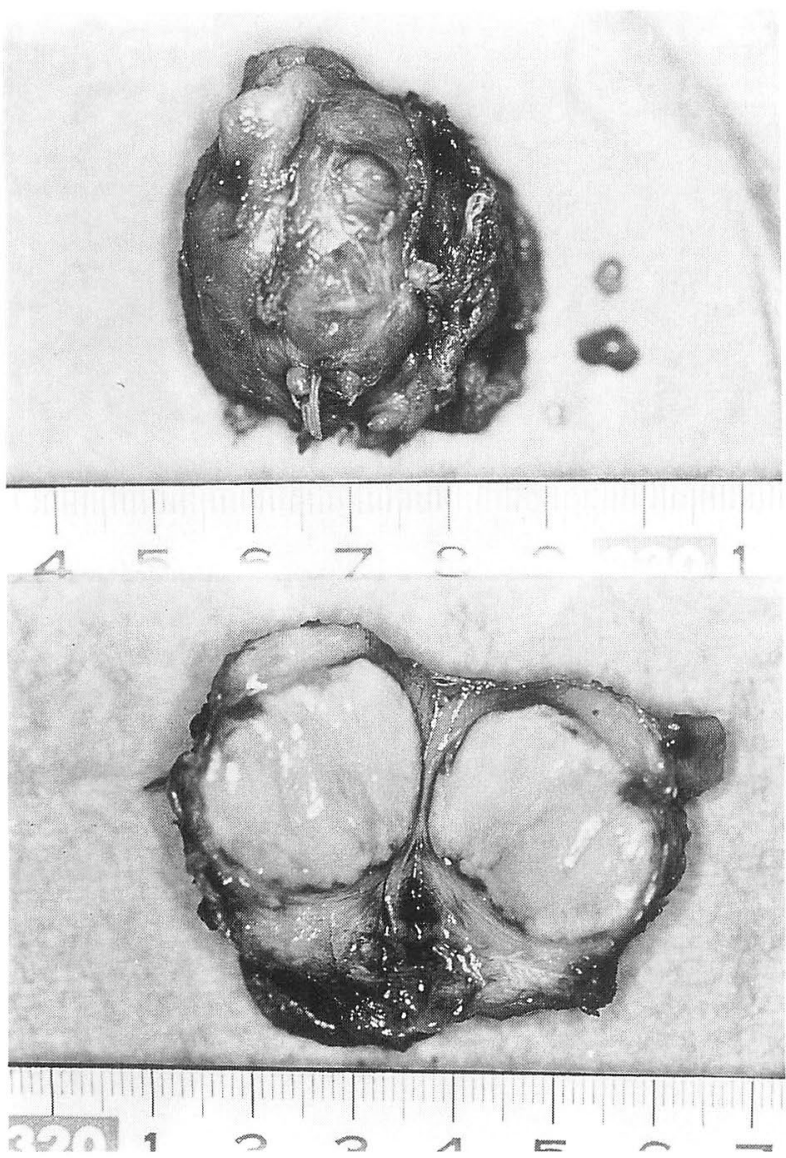

図 3 摘出標本の肉眼所見

弾性硬，一部結節状で被膜に覆われ，割面は黄色〜白色 で一部壞死を伴い, 充実性の腫瘍.

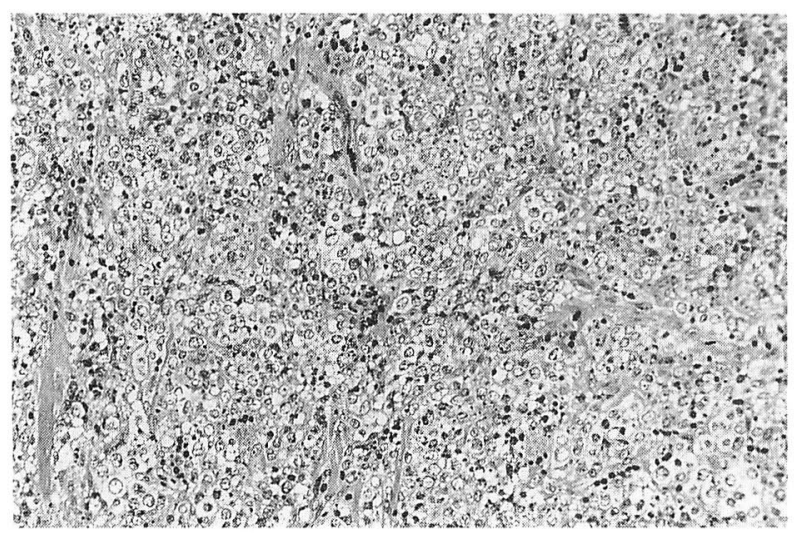

図 4 病理組織 $(\mathrm{HE}$ 染色, $\times 200)$

壞死を伴いび慢性に増生する腫瘍細胞.

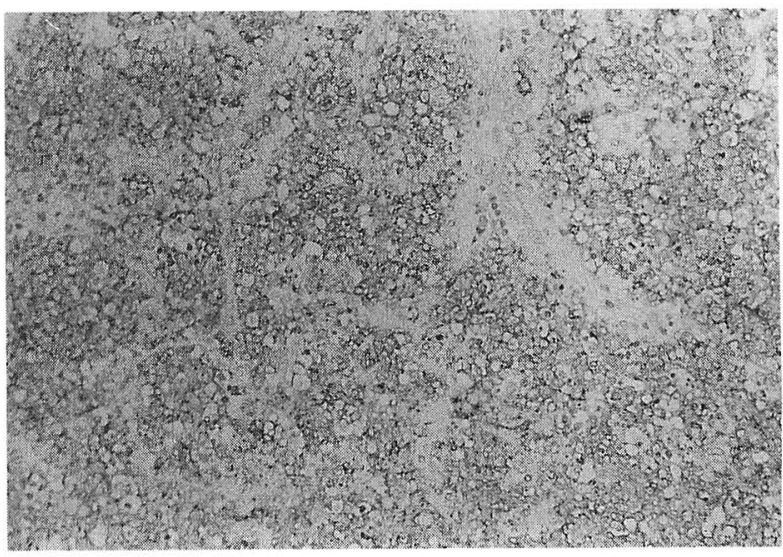

図 5 免疫組織 $($ L26 染色, $\times 200)$

B cell 系の L26 染色で細胞膜の染色を認める.

は非ホジキンリンパ腫である。原発部位について，過去 の報告1) 3) では，ワルダイエル輪44〜 59\%，リンパ節外 18〜 37\%, 頸部リンパ節 $5 \sim 23 \%$, ワルダイエル輪原 発が最も多く, 頸部リンパ節に原発するものは少なく, 副咽頭間隙内のリンパ節に発生したとする報告は極めて 少ない。

本邦での副咽頭間隙に発生した腫瘍の報告は，宮原 ら4)により1976年までの77例，小崎ら5)により1977年か ら1987年までの124例が集計されている。この2つの集 計をまとめると，副咽頭間隙に発生する腫瘍の内，良性 腫瘍が181例 $(90 \%)$ ，悪性腫瘍が20例(10\%)であり，圧 倒的に良性腫瘍が多い。良性腫瘍の中では，混合腫瘍70 例，神経原性腫痬84例と，この両者が全体の77\%を占め ていた，悪性腫瘍の中では，悪性リンパ腫が 6 例で，そ の他，悪性混合腫瘍，腺癌などが多かった，欧米の例を 見ると，Som ら6)によれば，104例中74例(71\%)が良性 腫瘍，30例 (29\%)が悪性腫瘍であった。良性腫瘍の中で は，混合腫瘍が29例，神経原性腫瘍が15例，グロームス 腫瘍が 9 例であった．悪性腫瘍の中では，悪性リンパ腫 が 9 例, 転移性扁平上皮癌が 9 例, 悪性耳下腺腫瘍が 11 例であった。 その他, Whyte ら7), Stell ら 同様に，混合腫瘍と神経原性腫瘍が多かった。 Whyte ら7)の報告では，30例中悪性腫瘍が14例(47\%)を占め, 悪性リンパ腫が 7 例, 扁平上皮癌が 7 例であった。今回, 我々が経験した悪性リンパ腫は, 本邦では比較的少なく, 副咽頭間隙腫瘍全体の約 $3 \%$ であった(表 1 ) 9) 12). 
表 1 副咽頭間隙悪性リンパ腫症例 $($ 1987)

\begin{tabular}{|c|c|c|c|c|c|c|c|c|c|}
\hline 症例 & 初診 & 年齢 & 性 & 主 訴 & 患側 & 組織分類 & 表面マーカー & 治 療 & 予後 \\
\hline $1^{9)}$ & 1973 & 56 & 男 & 咽頭痛 & 右 & 不 明 & 不 明 & $\mathrm{COP}, 6000 \mathrm{rad}$ & 寛解 \\
\hline $2^{10)}$ & 1980 & 61 & 男 & 咽頭痛 & 左 & 不 明 & 不 明 & 不 明 & 寛解 \\
\hline $3^{10)}$ & 1981 & 51 & 男 & 咽頭痛 & 左 & 不 明 & 不 明 & 不 明 & 死亡 \\
\hline $4^{11)}$ & 不明 & 77 & 女 & 咽頭痛 & 左 & diffuse, mixed type & B細胞型 & $\mathrm{COP}, 3850 \mathrm{rad}$ & 死亡 \\
\hline $5^{(1)}$ & 不明 & 3 & 男 & 曣下障害 & 右 & diffuse, histiocytic & B 細胞型 & $\mathrm{LSA}_{2} \mathrm{~L}_{2}, 2100 \mathrm{rad}$ & 寛解 \\
\hline $6^{12)}$ & 1982 & 14 & 男 & 右軟口蓋腫脹 & 右 & diffuse & B 細胞型 & CHOP, $2880 \mathrm{rad}$ & 寛解 \\
\hline
\end{tabular}

副咽頭間隙に発生する腫瘍の診断には, 腫瘍の存在範 囲, 腫瘍と周囲組織との関係を知ることが重要で, 現在, CT P MRI が利用されている. 腫瘍の質的崄断につい てはSom 5613114) が，CT，MRIを用いて，詳細に検討 している．悪性リンパ腫についても検討しているが， CT では, 筋肉より CT 值が低いか等しく, 通常は造影 されないが，CT だけでは壊死性および転移性のリンパ 節と区別できないと述べている，MRIでは，T1 強調画 像では筋肉と等信号, T2 強調画像では比較的高信号で, 内部は均質で，辺縁は比較的整であるが，アデノイドな どのリンパ組織, 唾液腺腫瘍, 神経原性腫痬との区別は できないと述べている．今回の症例では，画像診断拈よ び理学所見上, 壊死性リンパ節炎, 転移性リンパ節, 神 経原性腫瘍との鑑別が困難であった。

生検に関して, Heeneman ら ${ }^{15)}$ は腫瘍散布, 出血の 危険性などの理由により，悪性を疑う症例のみに行うべ きであると述べている. 今回我々は良性腫瘍と悪性腫瘍 との鑑別のために，穿刺吸引細胞診，頸部外切開拈よび 術中迅速診断を行ったが，診断を得ることができなかっ た．原因としては，腫瘍が被膜で覆われて扣り生検のた めには被膜を介して腫瘍実質を深く鉗除しなければなら ず，小片の試料のみでは診断が困難な悪性リンパ腫であ ったためと考えられた。

今回の症例検討で, 悪性の副咽頭間隙腫瘍が疑われる 場合には悪性リンパ腫も念頭に置き，生検に際しては十 分な量の試料を採取し，免疫組織も含めて病理組織診断 に供する必要があることを再確認させられた。

$$
\text { まとめ }
$$

副咽頭間隙に発生する腫瘍は良性腫瘍が注とんどで, 悪性腫瘍が発生することは稀である，本邦において同部
位に悪性リンパ腫が発生したとする報告は極めて少ない。 今回, 我々は, 副咽頭間隙に発生し, 診断に苦慮した 悪性リンパ腫の 1 例を経験したので若干の文献的考察を 加えて報告した。

\section{参考文献}

1) 河野嘉彦, 夜陣紘治, 世良公志, 他：当科に扣ける頭頸部 悪性リンパ腫の統計的観察. 耳鼻臨床 補 $27: 237 \sim 247$, 1988.

2 ）山中 昇: 悪性リンパ腫の治療. JOHNS 7:101〜108, 1991.

3 ) 八尾和雄, 高橋廣臣, 岡本牧人, 他: 当教室で経験した non-Hodgkin リンパ腫82症例の検討. 耳鼻臨床 補 $42: 188$ $\sim 194,1991$.

4 ) 宮原 裕, 東家倫夫, 高村善夫, 他 : 副咽頭間隙に発生す る腫瘍 一症例報告及び文献的考察一。耳喉 $50: 35 \sim 43$, 1978.

5 ）小崎寛子, 庄司 稔, 平塚宗雄, 他 : 巨大な副咽頭間隙腫 瘍の 4 例. 耳鼻臨床 $83: 429 \sim 442,1990$.

6 ) Som PM, Biller HF, Lawson W, et al : Parapharyngeal space masses ; an update protocoal based upon 103 cases. Radiology $153:$ 149 156, 1984.

7 ) Whyte AM and Houriban MD : The diagnosis of tumours involving the parapharyngeal space by computed tomography. Br J Radiol 62 : 526 531, 1989.

8 ) Stell PM, Mansfield AO and Stoney PJ : Surgical approaches to tumors of the parapharyngeal space. Am J Otolaryngol $6: 92 \sim 97,1985$.

9 ) 湧谷忠雄, 小林仁和, 小野一乗 : 特異な経過をたどった咽 頭細網肉腫症例. 耳喉 $46: 401 \sim 403,1974$.

10）竹内 亘, 生駒尚秋, 横山道明, 他 : 副咽頭腫瘍14例の検 討. 耳鼻臨床 $78: 1806 \sim 1812,1985$.

11) Ogasawara H, Fujitani T, Kimura J, et al : Malignant lymphoma presenting as a paroid mass. Auris Nasus Larynx $10: 61 \sim 68,1983$. 
12) Ogasawara H, Kimura J, Morisaki $Y$, et al : Malignant lymphoma in unusual areas of the head and neck; parapharyngeal space and temporal fossa. Auris Nasus Larynx $12:$ 125 133, 1985.

13) Som PM, Sacher M, Stollman AL, et al : Common tumors of the parapharyngeal space; refined imaging diagnosis. Radiology $169: 81 \sim 85,1988$.

14) Som PM, Braun IF, Shapiro MD, et al : Tumors of the parapharyngeal space and upper neck; MR imaging characteristics. Radiology $164: 823 \sim 829,1987$.

15) Heeneman $H$, Gilbert $J$ and Rodd SR : Parapharyngeal space tumors. Clin Otolaryngol $4: 57 \sim 66,1979$.

別刷請求先 : 山谷浩信 T040 函館市弥生町2-33

市立函館病院耳鼻咽喉科) 